\title{
Effect of Chestnut Tannin on Fermentation Quality, Proteolysis, and Protein Rumen Degradability of Alfalfa Silage
}

\author{
E. Tabacco, ${ }^{*}$ G. Borreani, ${ }^{* 1}$ G. M. Crovetto, $\uparrow$ G. Galassi, $\dagger$ D. Colombo, $†$ and L. Cavallarin $\ddagger$ \\ *Dipartimento di Agronomia, Selvicoltura e Gestione del Territorio, Università degli Studi di Torino, Grugliasco, Torino, Italy \\ †Istituto di Zootecnia Generale, Università degli Studi di Milano, Milano, Italy \\ †lstituto di Scienze delle Produzioni Alimentari, CNR, Grugliasco, Torino, Italy
}

\section{ABSTRACT}

Two experiments were conducted on alfalfa to investigate the effects of the addition of commercial chestnut hydrolyzable tannin at ensiling on 1) silage fermentation quality in lab-scale silos and protein degradation in the rumen, and 2) silage fermentation quality and proteolysis in bale silages. Wilted alfalfa was prepared with 4 tannin levels $(0,2,4$, and $6 \%$ on a dry matter (DM) basis; T0, T1, T2, T3, respectively) and ensiled in lab-scale silos. Silages (33\% DM) were analyzed for fermentation quality, protein rumen degradability in situ, and organic matter digestibility in vitro through gas production after $120 \mathrm{~d}$ of conservation. Wilted alfalfa containing 0 and $4 \%$ tannin (T0 and T2) was harvested at $40 \% \mathrm{DM}$ (wilting level I) and 53\% DM (wilting level II) for bale (600 mm diameter) silage. Silages were analyzed for fermentation quality after $78 \mathrm{~d}$ of conservation. All the silages were well fermented with no butyric acid. Lab-scale silages showed reductions in ammonia, nonprotein nitrogen (NPN) and DM losses in T2 and T3 treatments, while the fermentation acid profiles were unaffected. In experiment 1 , the untreated silage (T0) had the highest protein degradability after being incubated in the rumen. The addition of tannin reduced crude protein ruminal disappearance in a dose-dependent manner. However, the tannin reduced the organic matter digestibility by $5.1 \%$ for all of the tannin addition levels. The tannin positively affected the silage quality in the round bale silages, in particular reducing ammonia and NPN in the lowest wilting level. In both experiments, T2 treatment reduced proteolysis without any influence of DM on the binding reaction and reduced the NPN by $15 \%$ in comparison to the control.

Key words: alfalfa lab-scale and bale silage, chestnut tannin, rumen protein degradability, silage proteolysis

\section{INTRODUCTION}

Forage legumes are important sources of homegrown protein on farms, especially after the implementation

Received March 9, 2006.

Accepted June 27, 2006

${ }^{1}$ Corresponding author: giorgio.borreani@unito.it of the ban on the use of meat and bone meal in animal nutrition in the European Union. The use of on-farmproduced protein can reduce the dependency on expensive imported proteins and can help in tracing food of animal origin along the production chain. Alfalfa is the most cultivated legume crop in northern Italy due to its high productivity and high nutritional value. If properly managed, alfalfa can provide up to $3,000 \mathrm{~kg}$ of CP per hectare (Tabacco et al., 2002). However, proteins of alfalfa harvested for silage at the recommended early maturity stage are often poorly utilized by ruminants because of the extensive breakdown to NPN compounds during wilting and storage (Muck et al., 2003). The main consequence of this process is the inefficient utilization of $\mathrm{N}$ by ruminants, which leads to the need of expensive supplemental protein in silage-based diets, whether for dairy (Broderick, 1995) or beef (Charmley et al., 1999) cattle. Furthermore, the inefficient capture of dietary $\mathrm{N}$ from silage increases the excretion of $\mathrm{N}$ into the environment by ruminants, which can be of concern in intensive ruminant livestock production areas (Tamminga, 1992). The proteolysis process during ensiling is due to the combined action of both plant and silage microbial enzymes, which can reduce the original herbage true protein content by up to $80 \%$ by the end of the conservation period (Winters et al., 2000). Furthermore, due to the action of rumen microflora, the residual protein is readily degraded in the rumen, with liberation of ammonia (Givens and Rulquin, 2004). It has been reported that in tannin-containing species, such as sainfoin (Onobrychis viciifolia Scop.) and Lotus spp., the protein degradation process during ensiling (Albrecht and Muck, 1991) and in the rumen (Broderick and Albrecht, 1997) is reduced in comparison to nontannin containing legumes such as alfalfa. Tannins are secondary plant metabolites that react with proteins, making them resistant to breakdown by proteases both in the silo (Salawu et al., 1999) and in the rumen (Messman et al., 1996). After ingestion, they can bind proteins at ruminal $\mathrm{pH}$, preventing bacterial proteolysis to occur, whereas they can allow protein release at abomasum level. Tannins in Lotus corniculatus fed to sheep improved protein utilization with reductions in rumen 
ammonia concentrations of $27 \%$ and increased absorption of essential AA from the small intestine by $50 \%$, thus improving milk production, daily weight gain, and the ovulation rate (Barry and McNabb, 1999). On the other hand, tannins at higher levels than $5 \%$ of DM are generally regarded as antinutritional factors for livestock (Makkar, 2003).

The reversible protein-binding properties of tannins suggest their employment as silage additives to reduce the severe proteolysis that occurs during the ensiling of forage. Commercially available tannins can be divided into 2 main groups: condensed and hydrolyzable tannins, with several uses ranging from the wine to the tanning industry. Chestnut (Castanea sativa L.) tannins are the most common hydrolyzable tannins extracted from temperate plants, and quebracho and mimosa are condensed tannins extracted from tropical plants. Condensed tannins added to grasses (Salawu et al., 1999) and hydrolyzable tannins added to legumes (Cavallarin et al., 2002) at ensiling have recently been shown to reduce protein degradation during conservation. The effects of condensed tannins on protein digestion are usually more negative than the effects of hydrolyzable tannins because they hydrolyze in gastric acidity beyond the rumen, releasing protein, $\mathrm{AA}$, and small units of phenolics that likely pass to the urine (Van Soest, 1994).

The following study was carried out to evaluate the effect of commercial chestnut tannin in 2 different experiments on 1) silage fermentation quality of alfalfa in lab-scale silos and on protein degradation in the rumen, and 2) silage fermentation quality and proteolysis at field scale in alfalfa bale silages.

\section{MATERIALS AND METHODS}

\section{Crop and Ensiling}

The 2 experiments were carried out over the 20012002 period in the Western Po plain near Torino $\left(44^{\circ} 50^{\prime} \mathrm{N}, 7^{\circ} 40^{\prime} \mathrm{E}\right.$, altitude $232 \mathrm{~m}$ above sea level, annual mean temperature $11.3^{\circ} \mathrm{C}$, and annual average rainfall of $751 \mathrm{~mm}$ ) on recent sandy-loam texture alluvium soil with a $\mathrm{pH}$ of 7.6. The first experiment was set up to define the level of effectiveness of tannin addition to alfalfa silage in lab-scale silos to achieve protein protection without compromising digestibility of the OM. The second trial was set up to study the effect of the determined tannin level on silage proteolysis and fermentation quality at field scale on wrapped bales.

\section{Experiment 1}

A fourth regrowth of alfalfa (cv. Equipe) was cut at early bloom on August 20, 2001, with yield of $2.8 \mathrm{t}$ of
$\mathrm{DM} / \mathrm{ha}, 23.5 \% \mathrm{DM}, 42.1 \% \mathrm{NDF}$ (DM basis), and $22.5 \%$ CP (DM basis). The herbage was cut with a mower and field-wilted with one tedding and harvested the following day at a DM content of around $35 \%$. The approximate moisture level was checked at regular intervals using a microwave oven. About $30 \mathrm{~kg}$ of wilted herbage was harvested and chopped with an experimental mechanical chopper to a length of 20 to $30 \mathrm{~mm}$. The chopped herbage was ensiled in sterile, 5 -L, laboratory glass silos equipped with a lid that only enables gas release. The tannins utilized were extracted from chestnut wood by heat and low-pressure treatment, and only the water-soluble fraction was kept and dehydrated. The chestnut tannin is commercially available as very fine powder (92 to $95 \% \mathrm{DM}$ ) with a pure tannin content of $77 \%$ on a DM basis. Four levels of pure chestnut tannin (Tannino C, Silva Chimica, s.r.l., Italy) addition were studied: without any additive (T0), tannin added at 2\% DM (T1), 4\% DM (T2), and 6\% DM (T3). The tannins were dissolved in water and dispensed with a hand sprayer in aliquots of $50 \mathrm{~mL} / \mathrm{kg}$ of fresh herbage during mixing in a concrete mixer. Four replications were performed for each treatment, for a total of 16 silos. The silos were weighed immediately before and after being filled and were then stored at $25^{\circ} \mathrm{C}$ for 120 d. During conservation, the silos were consecutively weighed at $1,4,7,14,20,27,48$, and $70 \mathrm{~d}$ and at the end of the conservation period to estimate the fermentation losses.

\section{Experiment 2}

A third regrowth of alfalfa (cv. Equipe) was cut on July 3,2002 , at full bloom with yield of $5.4 \mathrm{t}$ of $\mathrm{DM} / \mathrm{ha}$, $23.6 \% \mathrm{DM}$, and 17\% CP (DM basis). The herbage was cut with a mower and wilted in the field for $2 \mathrm{~d}$. Two different wilting levels (40 and 50\%) were compared and are subsequently referred to in the text as wilting levels I and II, respectively. Forage DM content in the field was determined with a microwave oven to assess the planned level for baling. The herbage was tedded twice during wilting. The planned DM contents were reached after $5 \mathrm{~h}$ and $28 \mathrm{~h}$, respectively, for the I and II wilting levels. The weather was favorable for field drying during the first day, but $3.5 \mathrm{~mm}$ of rain fell before the II wilting level was reached. The wilted herbage was raked before baling and treated in alternate windrows without any additive (T0) and with the addition of $4 \%$ $\mathrm{DM}$ of chestnut tannin (T2). The chestnut tannin was dissolved in water and dispensed in aliquots of $1.2 \mathrm{~L}$ per $12 \mathrm{~kg}$ of fresh herbage (about $6 \mathrm{~m}$ of windrow) with a 10-L knapsack sprayer. Herbage samples of $10 \mathrm{~kg}$ were taken at cutting and before ensiling, then chopped and subsampled for chemical analyses, with 4 replica- 
tions. The herbage was baled (Columbia R500/Z, Wolagri, Suzzara, Italy) in $600-\mathrm{mm}$ diameter round bales. Round bales were wrapped individually (FW 500/Z, Wolagri) within $3 \mathrm{~h}$ after baling using a stretch film (4 layers, $250 \mathrm{~mm}$ wide $\times 25 \mu \mathrm{m}$ thick). Four replications were performed at each DM level for the 2 treatments (T0 and T2) for a total of 16 bales. The bales were safely stored on their ends indoors at $25^{\circ} \mathrm{C}$ for $78 \mathrm{~d}$. During conservation, the bales were consecutively weighed at $1,3,7$, and $32 \mathrm{~d}$ and at the end of the conservation period to estimate the fermentation losses. The bales were opened and sampled at the end of conservation. Sampling was performed by coring the bale from its side to a depth of about $450 \mathrm{~mm}$ with a corer $(50 \mathrm{~mm}$ diameter).

\section{Sample Preparation and Chemical Analysis}

The herbage and silage samples were divided into 3 subsamples. The first subsample was immediately analyzed to determine the $\mathrm{DM}$ content at $80^{\circ} \mathrm{C}$ in a forced-draft oven until constant weight and ash (ASH) by ignition to $550^{\circ} \mathrm{C}$. The second subsample was freezedried in a lyophilizer (5Pascal, Trezzano sul Naviglio, Italy) for $2 \mathrm{~d}$. The vacuum level was $1 \times 10^{-1} \mathrm{mBa}$, and the temperature was $-40^{\circ} \mathrm{C}$. The lyophilized sample was ground in a Cyclotec 1093 sample mill (Foss, Hillerød, Denmark) to pass a 1-mm screen and used for determination of total $\mathrm{N}$, Met, Lys, total amino acids (TAA), and ether extract (EE). Total nitrogen was determined according to the Dumas method (Buckee, 1994) using a Nitrogen Analyser MicroN (Elementar, Hanau, Germany). Ether extract was determined following the AOAC method (1990). The third wet sample was homogenized and extracted for $4 \mathrm{~min}$ in a Stomacher blender (Seward Ltd, UK) in water or in $0.1 \mathrm{~N}$ $\mathrm{H}_{2} \mathrm{SO}_{4}$. The buffering capacity, $\mathrm{pH}$, and water-soluble carbohydrates were determined in the water extract as described in Cavallarin et al. (2005). Nonprotein N was determined according to the Kjeldahl method (AOAC, 1990) in the water extract after precipitation with TCA (final concentration $50 \mathrm{~g} / \mathrm{L}$ ) and phosphotungstic acid (final concentration $2 \mathrm{~g} / \mathrm{L}$ ), and centrifugation at 1,500 $\times g$ for 15 min at $4^{\circ} \mathrm{C}$. The ammonia $\mathrm{N}\left(\mathrm{NH}_{3}-\mathrm{N}\right)$ contents, determined using a specific electrode (Orion Research Inc., Boston, MA), were quantified in the water extract. The lactic and monocarboxylic acids (acetic, propionic, and butyric acids) were determined by HPLC (Canale et al., 1984). Ethanol was determined by HPLC, coupled to a refractive index detector, on an Aminex HPX-87H column (BioRad Laboratories, Richmond, CA). Analyses were performed isocratically under the following conditions: mobile phase, $0.0025 \mathrm{M} \mathrm{H}_{2} \mathrm{SO}_{4}$; flow rate, $0.5 \mathrm{~mL} / \mathrm{min}$; column temperature, $37^{\circ} \mathrm{C}$; and injection volume, $100 \mu \mathrm{L}$. Duplicate analyses were performed for all the determined parameters. Duplicates were averaged and the 4 means were considered as 4 observations in statistical analysis.

The $\mathrm{N}$ fractions were studied in detail in Experiment 2 to characterize the proteolysis during ensiling. Free AA-N was determined according to Winters et al. (2002) on water extracts. The TAA, Met, and Lys were determined according to Cavallarin et al. (2005) on freezedried samples.

\section{Protein Rumen Degradability}

In Experiment 1 silages were analyzed in situ to determine $\mathrm{N}$ rumen degradability. For this purpose, 3 rumen-fistulated Italian Friesian dry cows $(\mathrm{BW}=650$ $\mathrm{kg}$ ) were fed at maintenance a diet with a 75:25 forage to concentrate ratio and $13 \% \mathrm{CP}$ (DM basis). The forage was a first cut of permanent meadow hay $(12 \% \mathrm{CP}$ on $\mathrm{DM}$ basis) and the concentrate contained (\% on a DM basis) the following: corn meal, 21; wheat middlings, 20; dried beet pulp, 18; soybean meal, 14; wheat bran, 12; barley, 10; sugarcane molasses, 3 ; and mineral and vitamin supplement, 2 . For rumen incubation, 100- $\times$ 150 -mm nylon bags with a porosity of $53 \mu \mathrm{m}$ were used. Silage samples were dried at $55^{\circ} \mathrm{C}$ until constant weight and then milled in a 2-mm sieve mill. Each nylon bag was filled with approximately $3.5 \mathrm{~g}$ of silage $(11.6 \mathrm{mg}$ of $\mathrm{DM} / \mathrm{cm}^{2}$ bag surface area). The incubation times were $2,4,8,16,24,48$, and $72 \mathrm{~h}$. Six replications (2/cow) were obtained for each forage and incubation time. Nonincubated samples (degradability at time 0 ) and all the bags after rumen incubation were first washed with tap water and then in a washing machine for $15 \mathrm{~min}$ (cold water cycle). Bags were then dried at $55^{\circ} \mathrm{C}$ and the DM and CP losses were determined for each sample.

The kinetics of rumen degradability were calculated from the Ørskov and McDonald (1979) equation:

$$
\mathrm{p}=\mathrm{a}+\mathrm{b}\left(1-\mathrm{e}^{-\mathrm{ct}}\right)
$$

where $\mathrm{p}=$ potential degradability at time $t, a=$ soluble protein fraction, $b=$ potentially rumen degradable protein fraction, $c=$ degradation rate of fraction $b$ per hour, $\mathrm{t}=$ incubation time $(\mathrm{h})$. The parameters of the equations were determined using the Marquardt nonlinear regression procedure (SAS Institute, 2000).

Effective degradability $(\mathrm{P})$ was determined using the following equations, considering rumen outflow rates of 3 and 6\%/h (Ørskov and McDonald, 1979):

$$
\mathrm{P}(\%)=\mathrm{a}+\mathrm{b}(\mathrm{c} / \mathrm{c}+\mathrm{k})
$$

where $a, b$, and $c$ are the same potential degradability parameters and $\mathrm{k}$ is the rumen outflow rate $(\% / \mathrm{h})$. 


\section{In Vitro Gas Production}

In Experiment 1 in vitro gas production (GP) was determined according to the Menke and Steingass (1988) gas production procedure. Approximately 200 $\mathrm{mg}$ of forage was weighed, placed into a graduated glass syringe provided with a piston, and filled with $30 \mathrm{~mL}$ of buffered rumen fluid. Each incubation was completed in triplicate. The glass syringes containing samples and rumen fluid and buffer mixtures were incubated in a water bath at $39^{\circ} \mathrm{C}$ and the gas production was subsequently measured before incubation $(0 \mathrm{~h})$ and at 8,24 , and $48 \mathrm{~h}$ after incubation. Total gas values were corrected for blank incubation and hay and concentrate standards with known gas values provided by the Institute for Animal Nutrition, Hohenheim University, Stuttgart, Germany. One replicate taken from each of the 4 laboratory glass silos was used for each treatment: 16 silage samples were tested for the gas production analysis. The $\mathrm{OM}$ digestibility $(\mathrm{OMD}), \mathrm{ME}$, and $\mathrm{NE}_{\mathrm{L}}$ were calculated according to Menke and Steingass (1988):

$$
\begin{aligned}
& \mathrm{OMD}=15.38+0.8453 \mathrm{GP}+0.0595 \mathrm{CP} \\
& \quad+0.0675 \mathrm{ASH} ; \\
& \mathrm{ME}(\mathrm{MJ} / \mathrm{kg} \text { of } \mathrm{DM})=2.20+0.1357 \mathrm{GP} \\
& \quad+0.0057 \mathrm{CP}+0.0002859 \mathrm{EE}^{2} ; \\
& \mathrm{NE}_{\mathrm{L}}(\mathrm{MJ} / \mathrm{kg} \text { of } \mathrm{DM})=0.54+0.0959 \mathrm{GP} \\
& \quad+0.0038 \mathrm{CP}+0.0001733 \mathrm{EE}^{2} ;
\end{aligned}
$$

where GP is net production in $24 \mathrm{hr}$ in $\mathrm{mL} / 200 \mathrm{mg}$ of $\mathrm{DM}, \mathrm{CP}$ is in $\mathrm{g} / \mathrm{kg}$ of DM, EE is in $\mathrm{g} / \mathrm{kg} \mathrm{DM}$, and ASH is in $\mathrm{g} / \mathrm{kg}$ of DM.

A comparison was also made with the OMD and the $\mathrm{NE}_{\mathrm{L}}$ predicted by the NRC (2001) system from only the chemical analysis of the forage. In this case we assumed a discount factor of 0.918 corresponding to a feed intake level of 3 times the maintenance with a hypothetical $\mathrm{TDN}_{1 \mathrm{X}}$ of a diet equal to $74 \%$.

\section{In Vitro Protein Intestinal Digestibility}

In vitro protein intestinal digestibility was determined on silage samples previously incubated in the rumen for $16 \mathrm{~h}$, following the procedure reported by Calsamiglia and Stern (1995). Pepsin-pancreatin digestion of protein was calculated as TCA-soluble $\mathrm{N}$ divided by the total amount of sample $\mathrm{N}$ used in the assay, after rumen incubation.

\section{Statistical Analysis}

The chemical compositional data were analyzed for their statistical significance via an ANOVA, with their significance reported at a 0.05 probability level using a GLM procedure (SAS Institute, 2000). When the calculated values of $F$ were significant, the Ryan-EinotGabriel-Welsch range test was used to interpret any significant differences among the mean values.

The effects of tannin addition and wilting on the $\mathrm{N}$ fractions and AA composition of the silage were determined in Experiment 2 using the split-plot ANOVA, with wilting as the main factor. To discuss effects of ensiling on the $\mathrm{N}$ fractions and AA composition of silages compared with the original wilted herbage, mean values were compared by computing the $95 \%$ confidence intervals.

The NPN values of the silages of the 2 experiments were regressed on the DM content. The MANOVA analysis of covariance was used to verify the equivalence of the equations for the 2 treatments. This procedure allowed for the verification of the hypothesis of parallelism of the regression equations and, when this was not rejected, the analysis of covariance was used to evaluate the differences between the adjusted means.

Potential rumen degradability parameters and effective rumen degradability data were analyzed by ANOVA using a GLM procedure according to the following model:

$$
\mathrm{Y}_{\mathrm{ij}}=\mu+\mathrm{T}_{\mathrm{i}}+\mathrm{C}_{\mathrm{j}}+\mathrm{e}_{\mathrm{ij}}
$$

where $\mathrm{Y}_{\mathrm{ij}}=$ dependent variable; $\mu=$ general mean; $\mathrm{T}_{\mathrm{i}}=$ tannin treatment effect $(\mathrm{j}=1,4) ; \mathrm{C}_{\mathrm{j}}=$ cow effect $(\mathrm{k}=1,3)$; and $\mathrm{e}_{\mathrm{ij}}=$ residual error.

The applied model for the GP, OMD, $\mathrm{ME}$, and $\mathrm{NE}_{\mathrm{L}}$ was as follows:

$$
\mathrm{Y}_{\mathrm{i}}=\mu+\mathrm{T}_{\mathrm{i}}+\mathrm{e}_{\mathrm{i}}
$$

where $Y_{i}=$ dependent variable; $\mu$ = general mean; $T_{i}=$ tannin treatment effect $(i=1,4)$; and $e_{i}=$ residual error.

\section{RESULTS}

\section{Experiment 1}

The chemical composition of the silages is reported in Table 1. All the silages were well fermented with no butyric acid. The fermentation products were not affected by the tannin addition, with the exception of $\mathrm{T} 1$, in which higher concentrations of lactic and acetic acids and a corresponding lower $\mathrm{pH}$ were found. The addition of tannin decreased the NPN and ammonia values. The fermentation DM losses decreased with the 
Table 1. Alfalfa lab-scale silos (Experiment 1): Chemical composition of untreated and treated silages with different amounts of added chestnut tannin

\begin{tabular}{lccccc}
\hline & \multicolumn{5}{c}{ Treatments $^{1}$} \\
\cline { 2 - 5 } Item & T0 & T1 & T2 & T3 & SE \\
\hline DM, \% & 31.8 & 32.7 & 33.8 & 33.8 & 0.39 \\
pH & $4.47^{\mathrm{a}}$ & $4.04^{\mathrm{b}}$ & $4.36^{\mathrm{a}}$ & $4.34^{\mathrm{a}}$ & 0.06 \\
Lactic acid, \% of DM & $3.28^{\mathrm{b}}$ & $5.01^{\mathrm{a}}$ & $3.44^{\mathrm{b}}$ & $3.63^{\mathrm{b}}$ & 0.27 \\
Acetic acid, \% of DM & $0.63^{\mathrm{b}}$ & $1.27^{\mathrm{a}}$ & $0.58^{\mathrm{b}}$ & $0.72^{\mathrm{b}}$ & 0.11 \\
Butyric acid, \% of DM & $<0.01$ & $<0.01$ & $<0.01$ & $<0.01$ & - \\
Total N, \% of DM & 3.50 & 3.54 & 3.59 & 3.53 & 0.03 \\
NH N $^{-N}$ \% of total N & $12.8^{\mathrm{a}}$ & $11.4^{\mathrm{b}}$ & $10.0^{\mathrm{c}}$ & $9.6^{\mathrm{c}}$ & 0.52 \\
NPN, \% of total N & $75.9^{\mathrm{a}}$ & $72.9^{\mathrm{a}}$ & $66.1^{\mathrm{b}}$ & $64.6^{\mathrm{b}}$ & 1.41 \\
DM loss, \% of DM & $3.35^{\mathrm{a}}$ & $2.72^{\mathrm{b}}$ & $2.43^{\mathrm{c}}$ & $2.35^{\mathrm{c}}$ & 0.11 \\
\hline
\end{tabular}

${ }^{\mathrm{a}-\mathrm{c}}$ Means in rows with different superscripts differ $(P<0.05)$.

${ }^{1}$ Treatments: $\mathrm{T} 0=$ control; $\mathrm{T} 1=$ chestnut tannin $2 \%$ of DM; $\mathrm{T} 2=$ chestnut tannin $4 \%$ of DM; T3 = chestnut tannin $6 \%$ of DM.

increasing tannin level up to T2. The trend of the DM losses during fermentation is shown in Figure 1. The good fermentation pattern kept the DM losses under $3.5 \% \mathrm{DM}$. The loss of DM was reduced $(P<0.05)$ by the addition of $4 \%$ tannin. Increasing the tannin concentration to $6 \%$ did not further reduce DM loss.

The data related to the rumen degradability, kinetics of the protein fractions, and protein intestinal digestibility of the silages are reported in Table 2 . Increasing the tannin concentrations resulted in a significant decrease in the soluble protein fraction (fraction a) in a dose-dependent manner. On the other hand, tannins significantly increased the potentially rumen-degradable protein fraction (fraction $b$ ), with no effect on the rate of degradation of this fraction. As a result, the total potential degradability of CP was similar for the different treatments, despite a significant reduction in treatments T2 and T3 in comparison to T0 and T1.

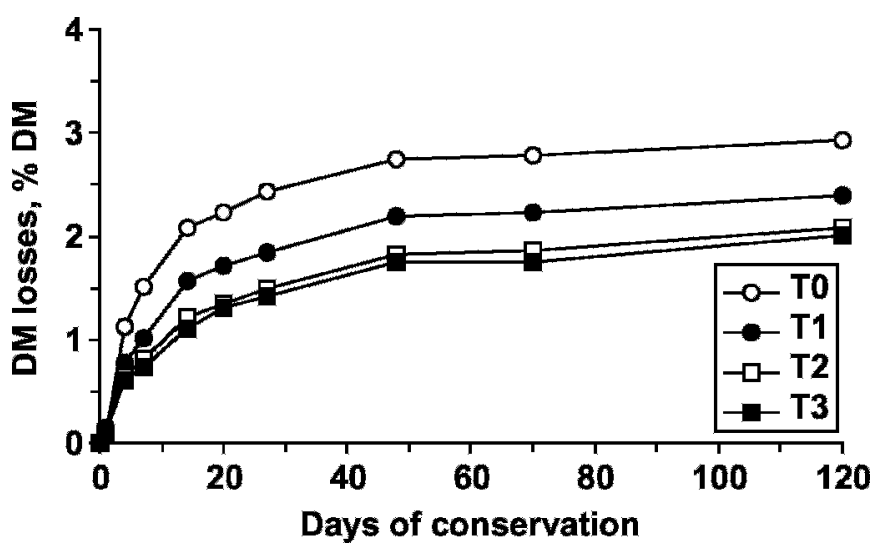

Figure 1. Alfalfa lab-scale silos (Experiment 1): DM losses during the conservation. Treatments: $\mathrm{T} 0=$ control; $\mathrm{T} 1=$ chestnut tannin $2 \%$ of DM; T2 = chestnut tannin $4 \%$ of DM; T3 = chestnut tannin $6 \%$ of DM.
Effective degradability was significantly decreased with increasing tannin concentrations for both the rumen 3 and $6 \% / \mathrm{h}$ outflow rates. It appears that 4 and $6 \%$ tannins tend to improve protein intestinal digestibility (no statistical analysis could be performed for this parameter due to the loss of some samples). The different kinetics of potential protein degradability of treatments T0, T1, T2, and T3 are shown in Figure 2. All the silages showed high protein degradability, especially the control (T0) silages mainly due to the very high soluble fraction. The fractions of the alimentary digestible protein in the intestine, calculated according to the French system (Vérite and Peyraud, 1988), were $1.03,1.12,1.56$, and $1.86 \% \mathrm{DM}$ for $\mathrm{T} 0, \mathrm{~T} 1, \mathrm{~T} 2$, and $\mathrm{T} 3$, respectively, and the fractions of microbial protein digestible in the intestine, considering $\mathrm{N}$ as the limiting factor, were $115.3,113.9,109.7$, and $107.4 \mathrm{~g} / \mathrm{kg}$ of DM for $\mathrm{T} 0, \mathrm{~T} 1, \mathrm{~T} 2$, and $\mathrm{T} 3$, respectively.

The values of $\mathrm{OMD}, \mathrm{ME}$, and $\mathrm{NE}_{\mathrm{L}}$, predicted from the GP and from the NRC system (2001), are reported in Table 3. Tannins lowered gas production, with a decrease in both the OMD and in the nutritive value of the silage in the same proportion for all the tested tannin concentrations.

\section{Experiment 2}

The composition of herbage at cut and before ensiling is reported in Table 4. Due to good weather conditions during the first day, the wilting reached the planned wilting levels (40\% and 50\% DM) after 5 and $28 \mathrm{~h}$ of field wilting, respectively. The wilting affected watersoluble carbohydrates and NPN content.

The chemical composition of the round bale silages is shown in Table 5. No butyric acid was detected in any of the silages. The tannin treatments had no effect on the fermentation quality, and a good fermentation pattern was observed in both treatment and wilting levels. The wilting level did not affect the lactic acid, acetic acid, or ethanol concentrations, which were not restricted in the most wilted silages, whereas DM losses were reduced in the silages at the highest wilting level $(P<0.01)$. The course of DM losses during fermentation is shown in Figure 3. The good fermentation pattern kept the DM losses under 3.0 and 2.0\% DM at the first and second wilting levels, respectively. The addition of $4 \%$ of tannin did not reduce the losses in any of the wilting levels.

The effect of the tannin addition and wilting on the silage $\mathrm{N}$ fractions is shown in Table 6. Tannin treatment affected all the $\mathrm{N}$ fractions except for total $\mathrm{N}$ and free AA-N. Tannin addition reduced the NPN $(P<0.01)$, ammonia $(P<0.001)$, and Met $(P<0.01)$ values, but it increased the TAA concentration $(P<0.05)$. The wilting 
Table 2. Alfalfa lab-scale silos (Experiment 1): Protein rumen degradability and intestinal digestibility of untreated and treated silage with different amounts of added chestnut tannin

\begin{tabular}{lllrrr}
\hline & \multicolumn{4}{c}{ Treatments $^{1}$} \\
\cline { 2 - 5 } & T0 & T1 & T2 & T3 & SE \\
\hline Fraction a $^{2}(\%)$ & $84.2^{\mathrm{a}}$ & $82.1^{\mathrm{b}}$ & $77.6^{\mathrm{c}}$ & $74.7^{\mathrm{d}}$ & 0.10 \\
Fraction $\mathrm{b}^{2}(\%)$ & $10.2^{\mathrm{d}}$ & $11.8^{\mathrm{c}}$ & $15.4^{\mathrm{b}}$ & $18.4^{\mathrm{a}}$ & 0.24 \\
Rate of degradation of fraction b $(\% / \mathrm{h})$ & 7.15 & 8.00 & 7.26 & 7.96 & 0.64 \\
Total potential degradability $(\mathrm{a}+\mathrm{b})$ & $94.3^{\mathrm{a}}$ & $93.9^{\mathrm{a}}$ & $93.0^{\mathrm{b}}$ & $93.2^{\mathrm{b}}$ & 0.23 \\
Effective degradability $($ rate $=3 \% / \mathrm{h})$ & $91.3^{\mathrm{a}}$ & $90.6^{\mathrm{b}}$ & $88.5^{\mathrm{c}}$ & $88.1^{\mathrm{c}}$ & 0.17 \\
Effective degradability $(\mathrm{rate}=6 \% / \mathrm{h})$ & $89.7^{\mathrm{a}}$ & $88.8^{\mathrm{b}}$ & $86.0^{\mathrm{c}}$ & $85.2^{\mathrm{d}}$ & 0.21 \\
Intestinal digestibility $(\%)$ & 39.8 & 40.0 & 44.6 & 50.9 & $-^{3}$ \\
\hline
\end{tabular}

${ }^{\mathrm{a}-\mathrm{d}}$ Means in rows with different superscripts differ $(P<0.05)$.

${ }^{1}$ Treatments: $\mathrm{T} 0=$ control; $\mathrm{T} 1=$ chestnut tannin $2 \%$ of DM; $\mathrm{T} 2=$ chestnut $\operatorname{tannin} 4 \%$ of DM; $\mathrm{T} 3=$ chestnut tannin $6 \%$ of DM.

${ }^{2}$ Fraction $\mathrm{a}=$ soluble protein fraction; fraction $\mathrm{b}=$ potentially rumen-degradable protein fraction.

${ }^{3}$ No statistical analysis available.

reduced the NPN $(P<0.001)$ and free AA-N $(P<0.05)$ and increased the TAA $(P<0.01)$ values.

Ensiling resulted in large increases in the NPN and free AA-N concentrations compared with the original wilted herbage (Table 4) with the largest increases corresponding to the untreated silages at both wilting levels. The level of Lys increased after ensiling by more than $100 \%$.

When the NPN values of the silage from treatments $\mathrm{T} 0$ and $\mathrm{T} 2$ of the 2 experiments were regressed on the DM content, 2 regression equations with high coefficients of determination were obtained $\left(\mathrm{r}^{2}=0.90\right.$ and 0.81 , respectively; Figure 4). The slopes of the 2 regression lines were not significantly different, whereas the constants differed significantly $(P<0.001)$, which means that the 2 lines are parallel.

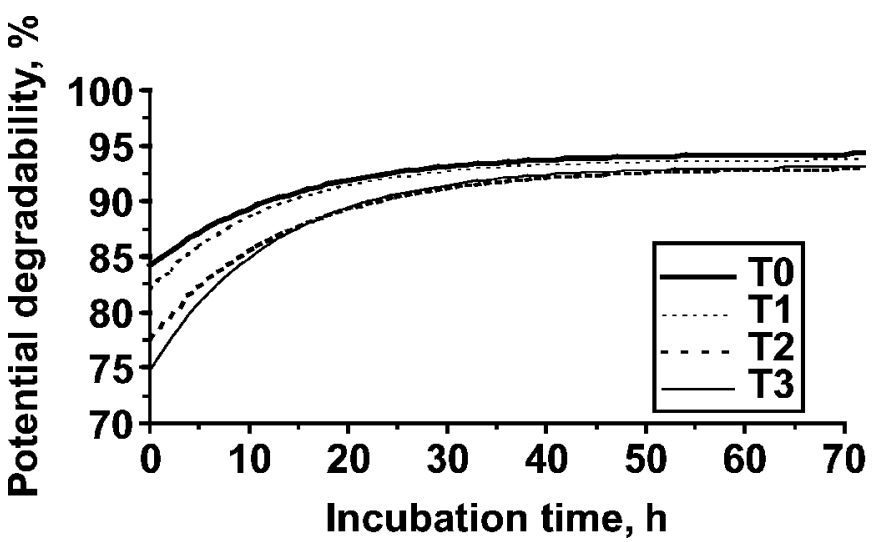

Figure 2. Alfalfa lab-scale silos (Experiment 1): Potential rumen degradability of proteins. Treatments: $\mathrm{T} 0=$ control; $\mathrm{T} 1=$ chestnut tannin $2 \%$ of DM; $\mathrm{T} 2$ = chestnut tannin $4 \%$ of $\mathrm{DM}$; $\mathrm{T} 3=$ chestnut tannin $6 \%$ of $\mathrm{DM}$

\section{DISCUSSION}

A considerable amount of information exists on the role of endogenous tannins on forage quality and their effect on ruminant nutrition (Sliwinski et al., 2002; Makkar, 2003). Very little information is available on the potential of tannins as silage additives during the ensilage of forages and their subsequent utilization by ruminants. Due to their binding activity, tannins can interact both with microorganisms and with dietary components, such as protein and carbohydrates (McSweeney et al., 2001).

\section{Silage Fermentation Characteristics and DM Losses}

Tannins are generally regarded as inhibitory to the growth of microorganisms and they could have some chemical or biological effects or both on the bacterial flora during ensiling. In the present experiments, the DM content of silages was compatible with good lactic acid fermentation, and no butyric acid was found in any of the silages. The tannin addition slightly influenced the pattern of fermentation products, and it had some effect on the DM losses in Experiment 1. Cavallarin et al. (2002) found that in alfalfa silages with a DM content ranging from 20 to $42 \%$ and with chestnut tannin added at $2.5 \%$ of DM, the butyric acid production was almost completely inhibited at all wilting levels. Kondo et al. (2004) found that the addition of green tea leaf waste (which is rich in tannins) to sudangrass silages promoted lactic acid production and did not affect acetate production. Salawu et al. (1999) found that the butyric acid concentration in perennial ryegrass silages with a DM content of $18.5 \%$ was reduced in silages treated with 0.5 and $5.0 \%$ (on a DM basis) of condensed tannin in comparison to the control. On the other hand, Salawu et al. (2001) found that the addition 
Table 3. Alfalfa lab-scale silos (Experiment 1): In vitro ruminal gas production (GP), OM digestibility, ME, and $\mathrm{NE}_{\mathrm{L}}$, calculated from GP, OM digestibility, and $\mathrm{NE}_{\mathrm{L}}$ predicted by the $\mathrm{NRC}(2001)$ system, of untreated and treated silage with different amounts of added chestnut tannin

\begin{tabular}{|c|c|c|c|c|c|}
\hline \multirow[b]{2}{*}{ Item } & \multicolumn{4}{|c|}{ Treatments $^{1}$} & \multirow[b]{2}{*}{ SE } \\
\hline & T0 & $\mathrm{T} 1$ & $\mathrm{~T} 2$ & T3 & \\
\hline $\mathrm{GP}, \mathrm{mL} / 24 \mathrm{~h}$ & $43.0^{\mathrm{a}}$ & $38.6^{\mathrm{b}}$ & $39.6^{\mathrm{b}}$ & $38.6^{\mathrm{b}}$ & 0.86 \\
\hline $\mathrm{OM}$ digestibility, $\%$ of $\mathrm{OM}$ & $73.0^{\mathrm{a}}$ & $69.2^{\mathrm{b}}$ & $69.8^{\mathrm{b}}$ & $68.8^{\mathrm{b}}$ & 0.73 \\
\hline $\mathrm{ME}, \mathrm{MJ} / \mathrm{kg}$ of DM & $9.57^{\mathrm{a}}$ & $8.96^{\mathrm{b}}$ & $9.08^{\mathrm{b}}$ & $8.92^{\mathrm{b}}$ & 0.12 \\
\hline $\mathrm{NE}_{\mathrm{L}}, \mathrm{MJ} / \mathrm{kg}$ of $\mathrm{DM}$ & $5.67^{\mathrm{a}}$ & $5.24^{\mathrm{b}}$ & $5.33^{\mathrm{b}}$ & $5.22^{\mathrm{b}}$ & 0.08 \\
\hline $\mathrm{OM}$ digestibility (NRC, 2001$),{ }^{2} \% \mathrm{OM}$ & 74.2 & 73.9 & 75.2 & 73.9 & - \\
\hline $\mathrm{NE}_{\mathrm{L}} 3 \times,{ }^{2} \mathrm{MJ} / \mathrm{kg}$ of $\mathrm{DM}$ & 5.67 & 5.64 & 5.77 & 5.62 & - \\
\hline
\end{tabular}

\footnotetext{
${ }^{\mathrm{a}, \mathrm{b}}$ Means in rows with different superscripts differ $(P<0.05)$.

${ }^{1}$ Treatments: $\mathrm{T} 0=$ control; $\mathrm{T} 1=$ chestnut tannin $2 \%$ of DM; $\mathrm{T} 2=$ chestnut tannin $4 \%$ of DM; $\mathrm{T} 3=$ chestnut tannin $6 \%$ of DM.

${ }^{2}$ According to NRC (2001).
}

of $0.57 \%$ (on a DM basis) quebracho tannin did not have any effect on fermentation products of pea and wheat bi-crop silage. In Experiment 2 the wilting treatment did not affect the silage fermentation in contrast to reports in several experiments (Muck et al., 2003). In Experiment 1 of the present work, the reduction in DM losses ranged from 19 to $29 \%$, with a tannin content that increased from 2.0 to $4.0 \%$ (on a DM basis), whereas a tannin concentration up to $6.0 \%$ did not further decrease the DM losses. Probably the $6 \%$ rate did not give a larger effect than the $4 \%$ rate because the complete inhibition of some microorganisms, such as enterobacteria, was already achieved at the $4 \%$ rate, as highlighted by similar levels of ammonia $\mathrm{N}$ in the 2 treatments. In Experiment 2, the DM losses were not affected by $4.0 \%$ (on a DM basis) of tannin. Increasing the wilting level from I to II reduced the losses by $33 \%$ due to the reduction of water activity and to the corresponding inhibition of fermentative microorganisms (McDonald et al., 1991) In a review on grass silage

Table 4. Alfalfa herbage (Experiment 2): Chemical composition and $\mathrm{N}$ fractions of fresh and wilted herbage

\begin{tabular}{lcccc}
\hline & & \multicolumn{2}{c}{ Wilting level $^{2}$} & \\
\cline { 3 - 4 } Item $^{1}$ & $\begin{array}{c}\text { Fresh } \\
\text { herbage }\end{array}$ & $\mathrm{I}$ & $\mathrm{II}$ & $\mathrm{SE}^{3}$ \\
\hline $\mathrm{pH}$ & 5.86 & 5.82 & 5.86 & 0.02 \\
$\mathrm{BC}, \mathrm{mEq} / \mathrm{kg}$ of DM & 435 & 436 & 382 & 12.5 \\
WSC, \% of DM & $4.78^{\mathrm{b}}$ & $6.55^{\mathrm{a}}$ & $6.45^{\mathrm{a}}$ & 0.37 \\
TN, \% of DM & 2.67 & 2.54 & 2.68 & 0.03 \\
NPN, \% of TN & $17.0^{\mathrm{b}}$ & $27.3^{\mathrm{a}}$ & $25.1^{\mathrm{a}}$ & 2.15 \\
Free AA-N, \% of TN & 8.04 & 7.71 & 8.35 & 1.36 \\
TAA, mol/kg of TN & 38.5 & 41.0 & 39.4 & 0.65 \\
Met, \% of DM & 0.285 & 0.269 & 0.209 & 0.02 \\
Lys, \% of DM & 0.383 & 0.370 & 0.402 & 0.01 \\
\hline
\end{tabular}

${ }^{\mathrm{a}, \mathrm{b}}$ Means in rows with different superscripts differ $(P<0.05)$.

${ }^{1} \mathrm{BC}=$ Buffering capacity; WSC = water-soluble carbohydrates; $\mathrm{TN}=$ total $\mathrm{N} ; \mathrm{TAA}=$ total $\mathrm{AA}$.

${ }^{2}$ Wilting levels: $\mathrm{I}=40 \% \mathrm{DM}$; II $=53 \%$ DM.

${ }^{3} \mathrm{SE}=$ Standard error $\left(d f_{\text {error }}=9\right)$. losses, McGechan (1990) reported that for gas-tight silos dominated by lactic acid bacteria fermentation, DM losses ranged from 2 to 4\%; Buckmaster et al. (1989) indicated that a typical alfalfa silage at a DM content of $35 \%$ will have about $1 \%$ fermentation loss.

\section{Nitrogen Fractions}

The second main characteristic of tannins is their capability of protecting protein by forming stable complexes in a pH range of 3.5 to 7.5 (Barry and McNabb, 1999). This is of particular interest for those plant species whose protein content is relevant for the formulation of ruminant ration, such as legumes. Alfalfa proteins undergo severe degradation due to both plant proteases during ensiling and to microbial proteases in the rumen (Broderick and Albrecht, 1997; Winters et al., 2000). The ensiling process caused an intensive proteolysis process in Experiment 2, with large increases in NPN, ammonia, and free AA values compared with the original herbage. Several factors have been shown to affect the level of proteolysis in the silo: the species of the forage (Albrecht and Muck, 1991), the stage of maturity of the crop (Kohn and Allen, 1995), the wilting level (Muck et al., 2003), and the rate of silage $\mathrm{pH}$ decline (McDonald et al., 1991). The increase in NPN was higher in the lowest wilting level silages, as previously reported for alfalfa (Muck et al., 2003). The NPN values found in the present experiments in the untreated silages for both laboratory and bale silages are consistent with those reported in literature from laboratory and farm alfalfa silos (Muck et al., 2003). The different stages of maturity influenced CP content $22.5 \%$ (Experiment 1) vs. $17 \%$ (Experiment 2). The higher NPN in Experiment 1 compared with Experiment 2 should be due to the lower DM content at ensiling and to the earlier stage of development of the crop. Cavallarin et al. (2000) in the same environment ob- 
Table 5. Alfalfa round bales (Experiment 2): Chemical composition of untreated and treated silage with added chestnut tannin at 2 wilting levels

\begin{tabular}{|c|c|c|c|c|c|c|c|c|c|}
\hline \multirow[b]{3}{*}{ Item } & \multicolumn{4}{|c|}{ Wilting level ${ }^{1}$} & \multirow[b]{3}{*}{$\mathrm{W}$} & \multirow[b]{3}{*}{$\mathrm{T}$} & \multirow[b]{3}{*}{$\mathrm{W} \times \mathrm{T}$} & \multirow{3}{*}{$\begin{array}{l}\text { Main } \\
\text { factor } \\
\text { SED }^{3}\end{array}$} & \multirow{3}{*}{$\begin{array}{l}\text { Subplo } \\
\text { SED }\end{array}$} \\
\hline & \multicolumn{2}{|c|}{ I } & \multicolumn{2}{|c|}{ II } & & & & & \\
\hline & $\mathrm{T}^{2}$ & $\mathrm{~T} 2$ & T0 & $\mathrm{T} 2$ & & & & & \\
\hline $\mathrm{DM}, \%$ & 41.5 & 38.2 & 55.5 & 51.5 & $*$ & NS & NS & 0.66 & 0.25 \\
\hline $\mathrm{pH}$ & 5.15 & 5.41 & 4.99 & 5.04 & NS & NS & NS & 0.22 & 0.17 \\
\hline Lactic acid, \% of DM & 3.26 & 3.54 & 3.05 & 4.33 & NS & NS & NS & 1.32 & 1.02 \\
\hline Acetic acid, \% of DM & 1.27 & 1.07 & 0.73 & 0.96 & NS & NS & $*$ & 0.47 & 0.19 \\
\hline Butyric acid, $\%$ of DM & $<0.01$ & $<0.01$ & $<0.01$ & $<0.01$ & - & - & - & - & - \\
\hline Ethanol, \% of DM & 0.53 & 0.57 & 0.44 & 0.53 & NS & NS & NS & 0.084 & 0.088 \\
\hline DM loss, \% of DM & 2.4 & 2.5 & 1.6 & 1.7 & $* *$ & NS & NS & 0.015 & 0.019 \\
\hline
\end{tabular}

served that the earlier stage of development (late vegetative vs. late bud) increased NPN by 6.4 to $7.4 \%$ (on a DM basis) in silages with DM content from 35 to $50 \%$. The same effect was observed by Kohn and Allen (1995) for alfalfa. Muck et al. (2003) reported a decrease of about 5.0\% NPN (on a DM basis) for an increase of 10 units of DM, and Cavallarin et al. (2000) observed differences from 7.7 to $8.4 \%$ NPN (on a DM basis) in butyric-acid-free silages of alfalfa. The relationships between NPN values and DM content of silages of the pooled data of the 2 experiments (treatments T0 and T2) showed a linear relationship with the same trend (no significantly different slopes). The $4 \%$ tannin treatment reduced the NPN mean value by 9.5 units, corresponding to a decrease of $15 \%$ compared with the control. This means that the tannin reduced proteolysis over the investigated DM range without the DM content

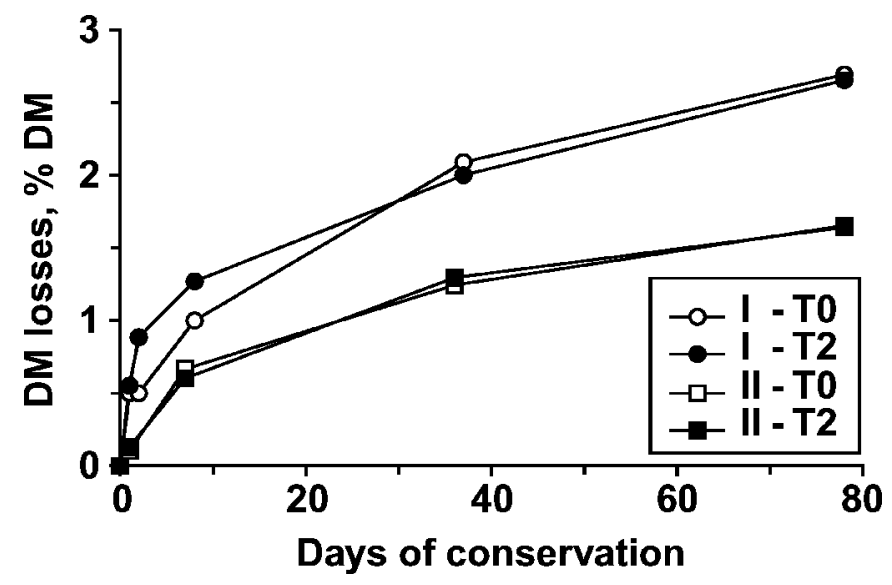

Figure 3. Alfalfa round bales (Experiment 2): DM losses during the conservation. Treatments: T0 $=$ control; $\mathrm{T} 2=$ chestnut tannin $4 \%$ of DM; I and II = wilting levels I $(40 \% \mathrm{DM})$ and II (53\% DM). having any influence on the binding reaction. The data obtained in the alfalfa silages with the addition of $4 \%$ chestnut tannin showed levels of NPN close to those found in silage made from condensed tannin containing legumes, such as sulla (Hedysarum coronarium L.; Valente et al., 1999) and sainfoin (Cavallarin et al., 2005). The condensed tannin contents of sulla and sainfoin ranged from 1.6 to $2.7 \%$ and 2.1 to $3.2 \% \mathrm{DM}$, respectively.

\section{OM Digestibility and Protein Degradability}

The data obtained in Experiment 1 indicate that tannins effectively reduce rumen protein degradation, with a reduction in the soluble fraction and an increase in the fraction degraded with time. This is consistent with the other results using several forages (Broderick and Albrecht, 1997; Salawu et al., 1999) and mixed diets for dairy cows (Sliwinski et al., 2002). Sliwinski et al. (2002) found that adding chestnut wood extract containing hydrolyzable tannins $(0.25 \% \mathrm{DM})$ to a basal diet for dairy cows reduced the level of rumen ammonia in comparison to the control. In Experiment 1 the reduction in rumen protein degradation of tannin-treated silages lead to a tannin dose dependent increase in the fraction of alimentary protein digestible in the intestine. On the other hand, the reduction in rumen OMD due to tannins determined a corresponding reduction in the fraction of microbial protein digestible in the intestine, considering $\mathrm{N}$ as the limiting factor. The trend of a higher intestinal protein digestibility in alfalfa treated with 4 and 6\% tannins on DM might be due to the fact that tannins reduce proteolysis in the rumen as they make protein complexes (McSweeney et al., 2001) that are resistant in the neutral $\mathrm{pH}$ of the forestomach, but become unstable in the acid ambient 
Table 6. Alfalfa round bales (Experiment 2): Nitrogen fractions of untreated and treated silage with added chestnut tannin at 2 wilting levels

\begin{tabular}{|c|c|c|c|c|c|c|c|c|c|}
\hline \multirow[b]{3}{*}{ Item $^{1}$} & \multicolumn{4}{|c|}{ Wilting level $^{2}$} & \multirow[b]{3}{*}{$\mathrm{W}$} & \multirow[b]{3}{*}{$\mathrm{T}$} & \multirow[b]{3}{*}{$\mathrm{W} \times \mathrm{T}$} & \multirow{3}{*}{$\begin{array}{l}\text { Main } \\
\text { factor } \\
\text { SED }^{4}\end{array}$} & \multirow{3}{*}{$\begin{array}{l}\text { Subplots } \\
\text { SED }\end{array}$} \\
\hline & \multicolumn{2}{|c|}{$\mathrm{I}$} & \multicolumn{2}{|c|}{ II } & & & & & \\
\hline & $\mathrm{T}^{3}$ & $\mathrm{~T} 2$ & T0 & $\mathrm{T} 2$ & & & & & \\
\hline $\mathrm{TN}, \%$ of $\mathrm{DM}$ & 2.50 & 2.37 & 2.54 & 2.54 & NS & NS & NS & 0.24 & 0.082 \\
\hline NPN, \% of TN & 61.2 & 53.7 & 46.6 & 41.6 & $* * *$ & $* *$ & NS & 1.56 & 3.92 \\
\hline $\mathrm{NH}_{3}-\mathrm{N}, \%$ of TN & 10.4 & 6.1 & 7.2 & 6.9 & NS & $* * *$ & $* * *$ & 2.32 & 0.59 \\
\hline Free AA-N, $\%$ of TN & 33.6 & 34.3 & 25.0 & 26.4 & $*$ & NS & NS & 3.57 & 3.17 \\
\hline $\mathrm{TAA}, \mathrm{mol} / \mathrm{kg}$ of $\mathrm{TN}$ & 33.2 & 36.9 & 37.1 & 39.9 & $* *$ & $*$ & NS & 0.98 & 2.28 \\
\hline Met, \% of DM & 0.197 & 0.171 & 0.241 & 0.175 & NS & $* *$ & NS & 0.034 & 0.038 \\
\hline Lys, \% of DM & 0.895 & 0.839 & 0.723 & 0.895 & NS & $*$ & $* *$ & 0.039 & 0.046 \\
\hline
\end{tabular}

${ }^{1} \mathrm{TN}=$ Total $\mathrm{N} ; \mathrm{TAA}=$ total $\mathrm{AA}$.

${ }^{2}$ Wilting levels: $\mathrm{I}=40 \% \mathrm{DM}$; II $=53 \% \mathrm{DM}$

${ }^{3}$ Treatments: $\mathrm{T} 0=$ control; $\mathrm{T} 2=$ chestnut tannin $4 \%$ of $\mathrm{DM} ; \mathrm{W}=$ wilting effect; $\mathrm{T}=$ treatment effect.

${ }^{4} \mathrm{SED}=$ Standard error of the difference $\left(d f_{\text {main factor }}=3\right)$.

$\mathrm{NS}=P>0.05 ; * P<0.05, * * P<0.01 ; * * * P<0.001$.

of the abomasum; thus, more digestible proteins are available for intestinal utilization in the gut.

The concept of using tannins to protect protein from degradation in the rumen is sound only as long as the tannin does not interfere with other ruminal activities. In the present experiment, the influence of tannins was positive in terms of a reduction of the extremely high $\mathrm{N}$ rumen degradability of the alfalfa silage and in terms of a shift of its digestible protein from the rumen to the

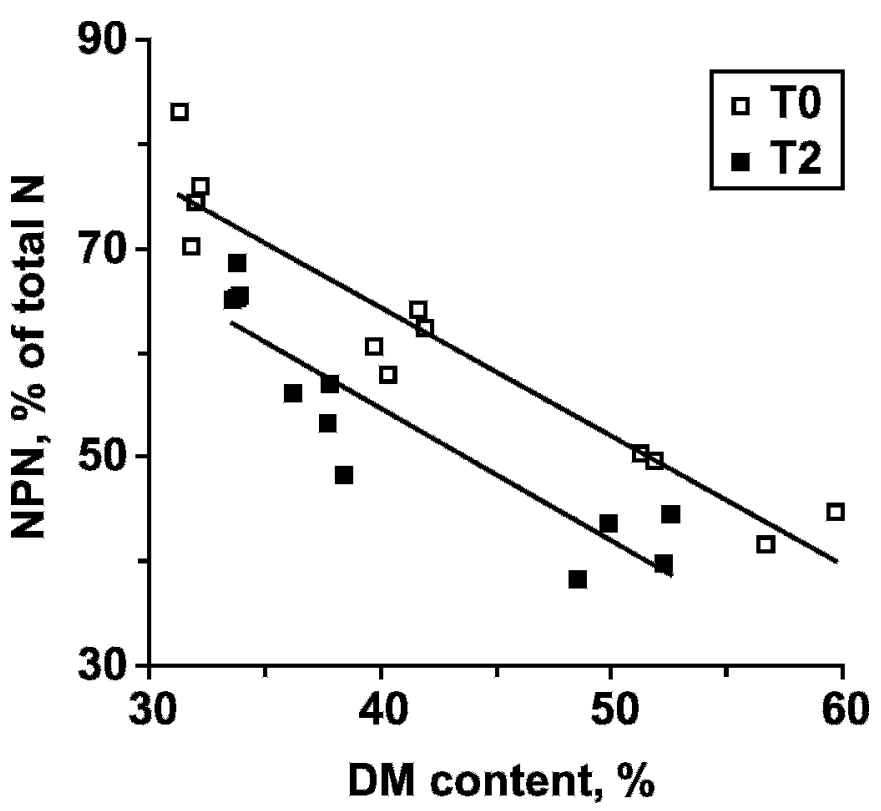

Figure 4. Alfalfa silage (Experiments 1 and 2): NPN values in relation to DM content of the silages as affected by tannin treatment T2 (chestnut tannin 4\% of DM). Regression obtained for control silages (T0) and for T2 tannin treatment were, respectively, a) NPN $(\% \mathrm{DM})=-1.229 \mathrm{DM}+113\left(\mathrm{r}^{2}=0.90 ;\right.$ root mean square error $(\mathrm{RMSE})=$ $4.1)$; and b) NPN $(\% \mathrm{DM})=-1.269 \mathrm{DM}+105\left(\mathrm{r}^{2}=0.81 ; \mathrm{RMSE}=4.8\right)$. intestine. However, the tannin reduced OM digestibility by about 3.7 units, corresponding to a reduction of $5.1 \%$ for all the tannin addition levels considered. Tannins significantly depressed GP, probably hampering rumen microorganisms. Cope and Burns (1971) observed negative effects of tannins on in vitro DM digestibility $(-25 \%)$ of high-tannin strains of sericea (Lespedeza cuneata) compared with low-tannin strains. McMahon et al. (2000) concluded that tannins do not simply inhibit cellulose digestion by ruminal fluid in vitro and in vivo, but that the inhibitory effects of tannins involved the bacterial cells themselves. Reductions in DM digestibility have been observed in vivo only when forages containing over 5\% DM condensed tannin are fed (Waghorn et al., 1990). In the present experiment, using the syringe method, an even lower level (2\% DM) of tannins inhibited rumen fermentation, with no possibility of recovery by the microbial population. The utilized in vitro system is a static system in comparison to the highly dynamic system of the rumen where a tannin-treated forage combines with other tanninfree feeds and a huge population of microorganisms. In the in vitro procedure, a sample of rumen fluid was in contact with alfalfa silage as the only alimentary substrate and the rumen microorganisms were able to utilize only alfalfa as energy source. McMahon et al. (2000) reported that the inhibitory effect of lower concentrations of condensed tannins in pure culture could reflect limited substrate availability for binding by condensed tannin in vitro. In vivo, the wider range and greater availability of substances in the rumen likely lowered the degree to which the condensed tannins inhibited the individual population of microorganisms. The positive effect of feeding alfalfa silage with the addition of $4 \%$ hydrolyzable chestnut tannin to dairy 
cows has been described by Colombari et al. (2005). The tannin affected the $4 \%$ FCM yield by increasing it by $1.5 \%$, and the milk protein daily yield by increasing it by $2 \%$ (with alfalfa accounting for $29 \% \mathrm{DM}$ of the diet).

The OMD and $\mathrm{NE}_{\mathrm{L}}$ values calculated from the combined biological and chemical analysis (GP) are similar to those predicted from the NRC equations for T0 but differed substantially for the tannin treated silages. The values of $\mathrm{OMD}$ and $\mathrm{NE}_{\mathrm{L}}$ are in fact 6 to $9 \%$ lower for $\mathrm{T} 1, \mathrm{~T} 2$, and $\mathrm{T} 3$ if compared with the corresponding NRC values. The data show that the chemical analysis alone is not predictive, due to the depressing influence of tannins on rumen fermentations, whereas Makkar et al. (1995) showed that the in vitro GP is a suitable method to evaluate the effects of antinutritional factors.

The results show that low levels of hydrolyzable chestnut tannin (4\% on a DM basis) applied prior to ensiling alfalfa are useful to reduce proteolysis in silages and could improve protein utilization, with a slight depression in OM digestibility. Further research is necessary to determine the optimal tannin levels for properly formulating rations for dairy cows, to investigate methods of applying tannin before ensiling in the field, and to evaluate the cost-effectiveness of the treatment to minimize out-farm protein purchase.

\section{ACKNOWLEDGMENTS}

The authors wish to thank Dario Sacco (Dipartimento di Agronomia, Selvicoltura e Gestione del Territorio, University of Turin) for his contribution in the statistical analysis, Sara Antoniazzi (Istituto di Scienze delle Produzioni Alimentari - Consiglio Nazionale delle Ricerche, Torino) for the laboratory analysis, and Silva Chimica s.r.l. of S. Michele di Mondovì (Italy) for providing the chestnut tannin. This work was supported in part by the Consiglio Nazionale delle Ricerche, "Agenzia 2000 Program", project no. CNRG0039EB. Part of this work was presented at the 21th General Meeeting of the European Grassland Federation (April 3-6, 2006, Badajoz, Spain). The authors contributed equally to the work described in this paper.

\section{REFERENCES}

Albrecht, K. A., and R. E. Muck. 1991. Proteolysis in ensiled forage legumes that vary in tannin concentration. Crop Sci. 31:464-469.

AOAC. 1990. Official Methods of Analysis. Vol. I. 15th ed. Association of Official Analytical Chemists, Arlington, VA.

Barry, T., and W. C. McNabb. 1999. The implications of condensed tannins on the nutritive value of temperate forages fed to ruminants. Br. J. Nutr. 81:263-272.

Broderick, G. A. 1995. Performance of lactating dairy cows fed either alfalfa silage or alfalfa hay as the sole forage. J. Dairy Sci. 78:320-329.

Broderick, G. A., and K. A. Albrecht. 1997. Ruminal in vitro degradation of protein in tannin-free and tannin-containing forage legume species. Crop Sci. 37:1884-1891.
Buckee, G. K. 1994. Determination of total nitrogen in barley, malt, and beer by Kjeldahl procedures and the Dumas combustion method. J. Inst. Brew. 100:57-64.

Buckmaster, D. R., C. A. Rotz, and R. E. Muck. 1989. A comprehensive model of forage changes in the silo. Trans. ASAE 32:1143-1152.

Calsamiglia, S., and M. Stern. 1995. A three-step in vitro procedure for estimating intestinal digestion of protein in ruminants. J. Anim. Sci. 73:1459-1465.

Canale, A., M. E. Valente, and A. Ciotti. 1984. Determination of volatile carboxylic acids (C1-C5) and lactic acid in aqueous acid extracts of silage by high performance liquid chromatography. J. Sci. Food Agric. 35:1178-1182.

Cavallarin, L., S. Antoniazzi, G. Borreani, P. G. Peiretti, E. Tabacco, and M. E. Valente. 2000. Effect of different levels of wilting on fermentation pattern of lucerne ensiled at two stages of maturity. Pages 50-52 in Proc. 18th Gen. Mtg. Eur. Grassl. Fed., Aalborg, Denmark. Br. Grassl. Soc., Reading, UK.

Cavallarin, L., S. Antoniazzi, G. Borreani, and E. Tabacco. 2005. Effect of wilting and mechanical conditioning on proteolysis in sainfoin (Onobrychis viciifolia Scop.) wilted herbage and silage. J. Sci. Food Agric. 85:831-838.

Cavallarin, L., S. Antoniazzi, G. Borreani, E. Tabacco, and M. E. Valente. 2002. Effect of chestnut tannin on protein degradation in lucerne ensiled at two stages of maturity. Pages 68-69 in Proc. 19th Gen. Meet. Eur. Grassl. Fed., La Rochelle, France. Br. Grassl. Soc., Reading, UK.

Charmley, E., J. A. Small, and K. B. McRae. 1999. Influence of postcalving supplemental protein on calf performance and reproductive efficiency for beef cows fed silage. Can. J. Anim. Sci. 79:97-106.

Colombari, G., G. M. Crovetto, G. Borreani, E. Tabacco, and G. A. Zapparoli. 2005. L'aggiunta di tannini per migliorare l'insilato di medica. Inf. Agric. 61:51-56.

Cope, W. A., and J. C. Burns. 1971. Relationship between tannin levels and nutritive value of sericea. Crop Sci. 11:231-233.

Givens, D. I., and H. Rulquin. 2004. Utilization by ruminants of nitrogen compounds in silage-based diets. Anim. Feed Sci. Technol. 114:1-18.

Kohn, R. A., and M. S. Allen. 1995. Effect of plant maturity and preservation method on in vitro protein degradation of forages. J. Dairy Sci. 78:1544-1551.

Kondo, M., K. Kita, and H. Yokota. 2004. Effects of tea leaf waste of green tea, oolong tea and black tea addition on sudangrass silage quality and in vitro gas production. J. Sci. Food Agric. 84:721-727.

Makkar, H. P. S. 2003. Effects and fate of tannins in ruminant animals, adaptation to tannins, and strategies to overcome detrimental effects of feeding tannin-rich feeds. Small Rumin. Res. 49:241-256.

Makkar, H. P. S., M. Blummel, and K. Becker. 1995. In vitro effects of and interactions between tannins and saponins and fate of tannins in the rumen. J. Sci. Food Agric. 69:481-493.

McDonald, P., A. R. Henderson, and S. J. E. Heron. 1991. The Biochemistry of Silage. 2nd ed. Chalcombe Publications, Bucks, UK.

McGechan, M. B. 1990. A review of losses arising during conservation of grass forage: Part 2, Storage losses. J. Agric. Eng. Res. 45:1-30.

McMahon, L. R., T. A. McAllister, B. P. Berg, W. Majak, S. N. Acharya, J. D. Popp, B. E. Coulman, Y. Wang, and K. J. Cheng. 2000. A review of the effects of forage condensed tannins on ruminal fermentation and bloat in grazing cattle. Can. J. Plant Sci. 80:469-485.

McSweeney, C. S., B. Palmer, D. M. McNeill, and D. O. Krause. 2001. Microbial interactions with tannins: Nutritional consequences for ruminants. Anim. Feed Sci. Technol. 91:83-93.

Menke, K. H., and H. Steingass. 1988. Estimation of the energetic feed value obtained from chemical analysis and in vitro gas production using rumen fluid. Anim. Res. Dev. 28:7-55.

Messman, M. A., W. Weiss, and K. A. Albrecht. 1996. In situ disappearance of individual proteins and nitrogen from legume forages containing varying amounts of tannins. J. Dairy Sci. 79:14301435.

Muck R. E., L. E. Moser, and R. E. Pitt. 2003. Postharvest factors affecting ensiling. Pages 251-304 in Silage Science and Technol- 
ogy. Vol. 42. D. Buxton, R. Muck, and J. Harrison, ed. ASA-CSSASSSA, Madison, WI.

National Research Council. 2001. Nutrient Requirements of Dairy Cattle. 7th rev. ed. Natl. Acad. Sci., Washington, DC.

Ørskov, E. R., and I. McDonald. 1979. The estimation of protein degradability in the rumen from incubation measurements weighted according to rate of passage. J. Agric. Sci. 92:499-503.

Salawu, M. B., T. Acamovic, C. S. Stewart, and T. Hvelplund. 1999 The use of tannins as silage additives: Effects on silage composition and mobile bag disappearance of dry matter and protein. Anim. Feed Sci. Technol. 82:243-259.

Salawu, M. B., E. H. Warren, and A. T. Adesogan. 2001. Fermentation characteristics, aerobic stability and ruminal degradation of ensiled pea/wheat bi-crop forages treated with two microbial inoculants, formic acid or quebracho tannins. J. Sci. Food Agric. $81: 1263-1268$.

SAS Institute. 2000. SAS User's Guide: Statistics. Version 8.01 ed. SAS Institute, Inc., Cary, NC

Sliwinski, B. J., C. R. Soliva, A. Machmüller, and M. Kreuzer. 2002. Efficacy of plant extracts in secondary constituents to modify rumen fermentation. Anim. Feed Sci. Technol. 101:101-104.

Tabacco, E., G. Borreani, M. Odoardi, and A. Reyneri. 2002. Effect of cutting frequency on dry matter yield and quality of lucerne (Medicago sativa L.) in the Po Valley. Ital. J. Agron. 6:27-33.
Tamminga, S. 1992. Nutrition management of dairy cows as a contribution to pollution control. J. Dairy Sci. 75:345-357.

Valente, M. E., P. G. Peiretti, G. Borreani, P. P. Roggero, G. Ladetto, and A. Ciotti. 1999. Influence of DM content on silage fermentation of sulla (Hedysarum coronarium L.) cut at two stages of maturity. Pages 119-120 in Proc. 12th Int. Silage Conf., Uppsala, Sweden. Br. Grassl. Soc., Reading, UK.

Van Soest, P. J. 1994. Nutritional Ecology of the Ruminant. 2nd ed. Cornell University Press, Ithaca, NY.

Vérite, R., and J. L. Peyraud. 1988. Nutrition azotée. Pages 75-93 in Alimentation des bovins, ovins et caprins. R. Jarrige, ed. INRA, Paris, France.

Waghorn, G. C., W. T. Jones, I. D. Shelton, and W. C. McNabb. 1990. Condensed tannins and the nutritive value of herbage. Proc. N.Z. Grassl. Assoc. 51:171-176.

Winters, A. L., J. E. Cockburn, M. S. Dhanoa, and R. J. Merry. 2000. Effects of lactic acid bacteria in inoculants on changes in amino acid composition during ensilage of sterile and non-sterile ryegrass. J. Appl. Microbiol. 89:442-451.

Winters, A. L., J. Lloyd, R. Jones, and R. J. Merry. 2002. Evaluation of a rapid method for estimating free amino acids in silages. Anim. Feed Sci. Technol. 99:177-187. 